\author{
WILLIAM D. NORDHAUS
}

Yale University

\title{
The Worldwide Wage Explosion
}

DURING THE DECADE PRIOR TO 1968, most of the industrial countries of the West experienced a period of tranquility in which prices were relatively stable and wage inflation moderate. Then quite suddenly-and, to judge from professional and political reaction, unexpectedly-wages and prices began to rise very sharply. Figure 1 shows the pattern of inflation for manufacturing wages from 1956 to 1971; the break in the trend in 1968 and the ascent to the peak in 1970 are clearly discernible. The wage histories of the seven countries to be considered in this paper are shown in Table $1 .{ }^{1}$ In each, wage inflation during the last four or five years rose noticeably over earlier years in the sixties.

The wage explosion has tested the ingenuity of economists, and they have not been found wanting. Countless discontinuous time series and special forces have been discovered to explain this surprising movement. But the diagnoses have a suspicious character. It is as if the doctors in a town hit by a plague all cite special factors to account for it: a cold, pneumonia, the population explosion, barometric pressure, in-laws' interference, psychosomatic disturbances, and so forth and so on. Isn't it curious that all the special factors hit all the countries at the same time?

1. The seven countries chosen for this study were Canada, France, Federal Republic of Germany (referred to hereafter as West Germany), Japan, Sweden, the United Kingdom, and the United States. The criteria of choice were that each country should (a) not be completely dominated by another country or by foreign trade, (b) have wages determined more or less in an industrial market framework, and (c) be at least slightly familiar to the author. 


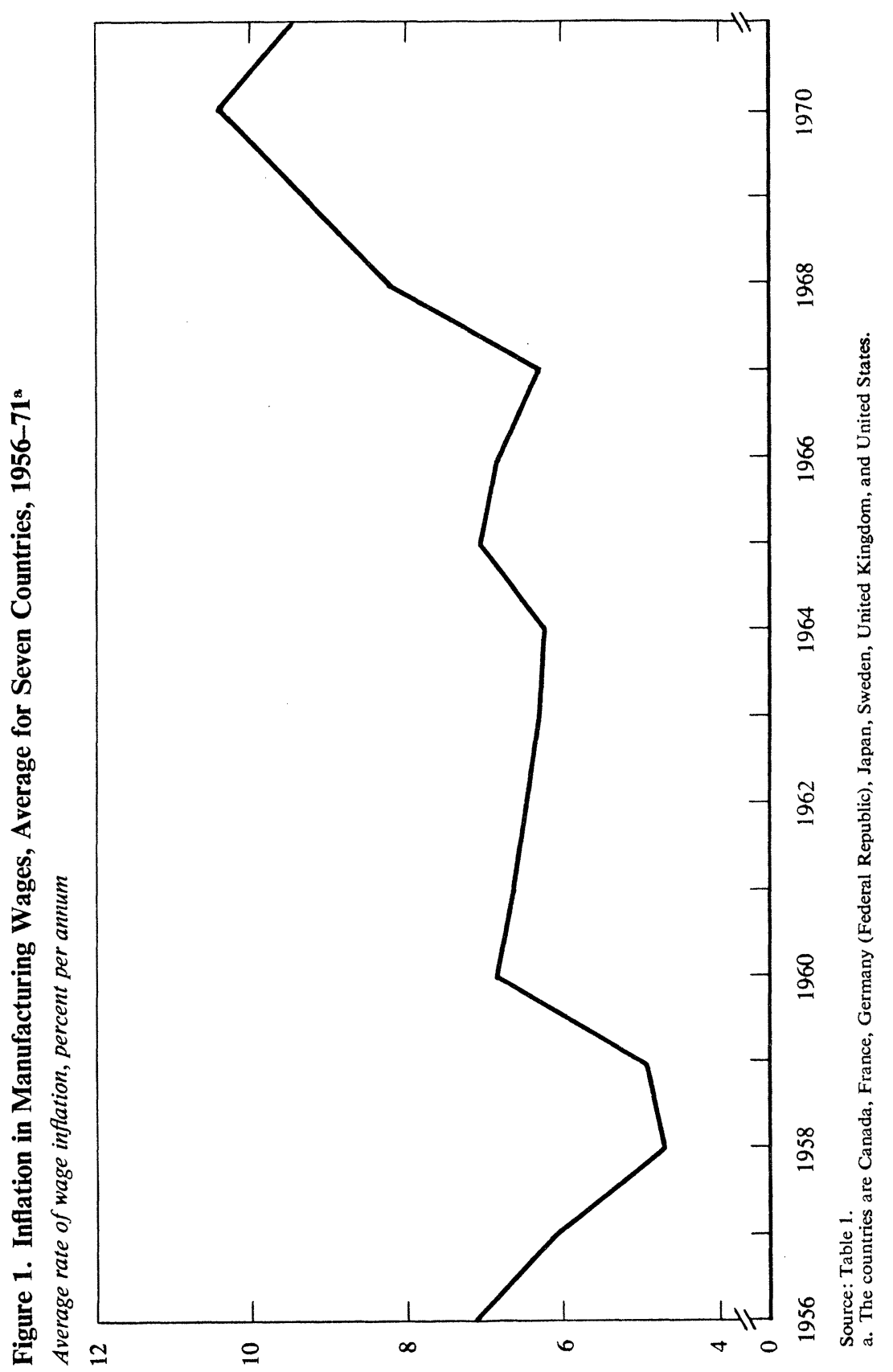


Table 1. Inflation in Manufacturing Wages in Seven Countries, 1956-71

Percentage change per yeara

\begin{tabular}{rrrrrrrr}
\hline Year & Canada & France & $\begin{array}{c}\text { West } \\
\text { Germany }\end{array}$ & Japan & Sweden & $\begin{array}{c}\text { United } \\
\text { Kingdom }\end{array}$ & $\begin{array}{c}\text { United } \\
\text { States }\end{array}$ \\
\hline 1956 & 4.7 & 6.8 & 9.3 & 9.1 & 8.1 & 7.1 & 4.7 \\
1957 & 5.7 & 7.5 & 9.5 & 2.7 & 6.0 & 6.6 & 5.0 \\
1958 & 3.0 & 11.5 & 6.4 & 2.1 & 4.3 & 3.0 & 2.8 \\
1959 & 3.5 & 5.8 & 5.6 & 8.0 & 4.1 & 3.9 & 3.7 \\
1960 & 3.4 & 6.9 & 10.4 & 8.2 & 6.5 & 9.2 & 3.1 \\
1961 & 2.7 & 7.3 & 10.1 & 9.2 & 8.4 & 5.9 & 2.6 \\
1962 & 2.6 & 8.1 & 10.7 & 9.6 & 6.7 & 4.0 & 2.9 \\
1963 & 3.6 & 8.2 & 6.8 & 10.0 & 8.3 & 4.3 & 2.8 \\
1964 & 3.5 & 6.9 & 7.7 & 9.2 & 5.8 & 7.2 & 2.8 \\
1965 & 4.8 & 5.4 & 9.6 & 8.6 & 10.7 & 6.6 & 3.1 \\
1966 & 5.9 & 5.8 & 7.0 & 11.5 & 7.3 & 5.9 & 4.1 \\
1967 & 6.4 & 5.8 & 3.9 & 11.8 & 9.0 & 3.2 & 3.9 \\
1968 & 7.2 & 11.7 & 4.0 & 14.4 & 6.2 & 8.1 & 6.1 \\
1969 & 7.8 & 10.5 & 9.7 & 15.9 & 7.7 & 7.6 & 5.8 \\
1970 & 7.5 & 10.1 & 11.2 & 14.4 & 12.3 & 11.9 & 5.1 \\
1971 & 8.5 & 10.5 & 11.1 & 12.6 & 7.4 & 10.7 & 6.0 \\
\hline
\end{tabular}

Sources: Economic Report of the President Together with the Annual Report of the Council of Economic Advisers, January 1972; United Nations, Statistical Yearbook, various issues; Orga nisation for Economic. Cooperation and Development, Main Economic Indicators: Historical Statistics, 1959-1969 (Paris: OECD, 1970), and Main Economic Indicators, various issues; and Department of Employment Gazette (London: Her Majesty's Stationery Office), various issues.

a. The wage inflation percentages in this table and elsewhere in the paper are expressed as first differences in the logarithms of hourly earnings of production workers (for Japan, all workers) in manufacturing. This logarithmic concept gives results that differ slightly from those obtained by the usual procedure of computing percentage changes.

The following is a sample of the explanations that have been put forth. In the first five groups are the theories that will be tested explicitly: ${ }^{2}$

1. Monetarist. Monetarists have argued that the recent inflation is but another incident in a long historic series induced by excessive growth of the money supply. A cosmic interpretation provided by Mundell is that the growing deficits in the U.S. balance of payments in the late 1960 s provided the reserves for excessive growth in the world's money supply that in turn led to the inflation.

2. Naïve Phillips curve. A second simple explanation is that tight labor markets, measured by low unemployment rates, gave rise to unusually high wage inflation in the late sixties.

3. Expectations Phillips curve. Perhaps the most popular explanation, especially in the United States and Britain, is that provided by the expecta-

2. Citations for theories 1 to 5 are contained in the relevant sections below. 
tions Phillips curve. This theory holds that "anticipated" inflation as well as tight labor markets produced the wage explosion.

4. Frustration theories. Turner and others have argued that the frustration arising from unusually low gains in real net wages have driven labor unions to increase their money wage demands, especially in Britain following the 1967 devaluation.

5. Export-constraint inflation. Several Scandinavian economists have put forth a theory (not directly related to the wage explosion) that argues for the importance of foreign trade prices as determinants of domestic wage and price movements.

Other factors, even less general, are sometimes held responsible for the recent wage explosion:

6. Threshold factors. Eckstein and Brinner have argued that when inflation reached a certain level, threshold factors changed the responsiveness of wage demands to past inflation. The same argument has been used by the Organisation for Economic Co-operation and Development (OECD), with respect to threshold effects and nonlinearities of response to tightness in labor market conditions in Germany. ${ }^{3}$

7. Social or labor union militance. Many analysts have joined the U.S. Council of Economic Advisers in seeing the wage explosion as partly the reflection of militance in social relations. They cite "trade union pushfulness" in the British wage inflation, the increasing militancy of labor in Japan, the French revolution of 1968, and "sociological and political factors" in the recent German wage inflation."

8. Demographic factors. Changing demographic patterns have been the focus of analysis for several authors. Perry argues that a weighted unemployment rate is a more appropriate index, while R. J. Gordon and others

3. See Otto Eckstein and Roger Brinner, The Inflation Process in the United States, prepared for the use of the Joint Economic Committee, 92 Cong. 2 sess. (1972); OECD, OECD Economic Surveys: Germany (Paris: OECD, June 1971), esp. Annex I, "Wages and Prices in Germany: An Econometric Study," pp. 45-53.

4. See Economic Report of the President Together with the Annual Report of the Council of Economic Advisers, February 1971, p. 61; A. G. Hines, "The Determinants of the Rate of Change of Money Wage Rates and the Effectiveness of Incomes Policy," in H. G. Johnson and A. R. Nobay (eds.), The Current Inflation (London: Macmillan, 1971), and earlier references cited there; OECD, Inflation: The Present Problem, Report by the Secretary General, December 1970; OECD Economic Surveys: France (Febraury 1972 and March 1970); Japan (June 1971), Annex, "Notes on the Labour Market and Wage Determination in Japan"; and Germany (1971) (the quotation appears on p. 9 of the last). 
have suggested quite the opposite, a disguised unemployment index. Perry, Brechling, and Lipsey have pointed to increased labor force dispersion as an important structural shift. ${ }^{5}$

9. Increased reservation price of labor. U.S. and British observers have suggested that workers have had an increasing reservation price for work, due either to psychological changes or to changes in unemployment compensation and other benefits. The effect was to shift out the Phillips curve and to stimulate greater wage inflation than would otherwise have been expected. ${ }^{6}$

10. Devaluation. British economists are virtually unanimous in citing the British devaluation of 1967 as at least partially responsible for the British wage explosion. ${ }^{7}$

While some of these special factors may prove to be significant, it is hard to accept such a collection of often ad hoc and for the most part local explanations as the reason for the pervasive inflation. The unmistakable trend revealed in Figure 1 makes the probability that the special factors all occurred at once too remote. But is there any unifying explanation?

Before examining the competing hypotheses, we want to clarify the methodological approach used here. The oversimplified theories presented below do not pretend to give the definitive view of money wage movements in each of the countries involved. Nor is the implication made that a careful analysis of the data or of special factors would not alter the results slightly for theory $x$ or country $y$, or that the richness of the institutional detail of individual labor markets is adequately discussed.

5. George L. Perry, "Changing Labor Markets and Inflation," Brookings Papers on Economic Activity (3:1970), pp. 411-41; Robert J. Gordon, "Inflation in Recession and Recovery," Brookings Papers on Economic Activity (1:1971), pp. 105-58; Frank Brechling, "Wage Inflation and the Structure of Regional Unemployment," forthcoming in Journal of Money, Credit and Banking; and Richard G. Lipsey, "The Relation between Unemployment and the Rate of Change of Money Wage Rates in the United Kingdom, 1862-1957, A Further Analysis," Economica, n.s., Vol. 27 (February 1960), pp. 1-31.

6. See the discussions by Gottfried Haberler, Michael Parkin, and Henry Smith, in Inflation and the Unions: Three Studies in the Effects of Labour Monopoly Power on Inflation in Britain and the USA (London: Institute of Economic Affairs, 1972); and "Comments," by Charles Schultze, Brookings Papers on Economic Activity (3:1970), pp. 442-44.

7. See H. A. Turner and Frank Wilkinson, "Real Net Incomes and the Wage Explosion," New Society (February 25, 1971), pp. 309-10; James E. Meade, Wages and Prices in a Mixed Economy (London: Institute of Economic Affairs, 1971); Frank W. Paish, How the Economy Works, and Other Essays (London: Macmillan, 1970), Chap. 8, "Rise and Fall of Incomes Policy," pp. 179-231; and the discussion of the Meade and Paish theories by Haberler in Inflation and the Unions. 
Rather, we are testing whether there is any simple explanation of the pervasive pattern of wage acceleration that all the countries have experienced. If, for example, the excess demand view is the correct one, a relatively straightforward explanation using a simple unemployment variable should turn up some relationship. On the other hand, if the excess demand theories explain little in the simplest formulation, a certain amount of healthy skepticism can properly be applied to further results that show excess demand to be of great significance.

In short, while the methods are very crude, they should cast considerable light on the relative merits of general theories about the wage explosion. It is primarily in the spirit of interpreting recent history that the present results are put forth.

\section{A Monetarist Wage Equation}

According to Milton Friedman, "Inflation is always and everywhere a monetary phenomenon, resulting from and accompanied by a rise in the quantity of money relative to output." If this position is correct and if changes in the stock of money are exogenous, the recent wage explosion should be explicable on monetarist grounds.

Although no one has, to my knowledge, attempted to use monetarist principles to explain money wage movements, the notion is implicit in the quantity theory framework. The simplest explanation relies on two general principles: ${ }^{9}$ First, the transactions velocity of money is stable, so that prices are proportional to the ratio of nominal money supply to real output.

8. Milton Friedman, "What Price Guideposts?" in George P. Shultz and Robert Z. Aliber, Guidelines, Informal Controls, and the Market Place (University of Chicago Press, 1966), p. 18. Mundell writes: "A plausible case can be made for a monetary cause of the current upward movement of world prices. From 1959 to 1964 the rate of inflation and the rate of world money expansion was very gentle. But from 1965 to 1971 the rate of monetary growth and the rate of increase in the price level accelerated all over the world. The result was the current inflation rates in excess of 5 percent. The simplest theory, that the monetary acceleration inspired the acceleration of prices, conforms to the facts." Robert Mundell, "World Inflation and the Eurodollar," forthcoming in Journal of Money, Credit and Banking.

9. Several people have pointed out that the assumptions here do not correspond exactly to all the views of all the monetarists. Subject to some of the caveats on lags, however, the model here does appear to contain the essence of the strict monetarist position. It should be made clear that the recent and more general work of the monetarists-especially that which is indistinguishable from modern "Keynesian" theoriescannot be tested adequately in the simple model used here. 
Second, all real magnitudes are determined by competitive and other market forces; further, since the real wage is a smooth trend, it can be adequately represented by the assumption of constant growth in (real) marginal productivity.

When these two assumptions are combined, the result, first, is

$$
p=\bar{V} M / X
$$

where

$$
\begin{aligned}
p & =\text { the price level } \\
\vec{V} & =\text { the (constant) velocity of money } \\
M & =\text { the money supply } \\
X & =\text { real output. }
\end{aligned}
$$

Second, the real wage is given by

$$
\frac{w}{p}=\exp \left[a_{0}^{\prime}+a_{1}^{\prime} t\right]
$$

where $w$ is hourly earnings per worker in manufacturing industries and $t$ is time.

Substituting (1) into (2) and taking logarithms results in the monetarist wage equation,

$$
\ln w_{\iota}=a_{0}+a_{1} t+a_{2} \ln M_{t}+a_{3} \ln X_{t} .
$$

Note that the constant velocity term is now subsumed in $a_{0}$. Two versions of this theory are used here. In the "constrained" version (1) and (2) are taken literally, and $a_{2}=-a_{3}=1$. In the "unconstrained" version, $a_{2}$ and $a_{3}$ are allowed to find their own values.

Because of the customary six-month lag between monetary impulse and the change in income, the money supply is lagged by one-half year in the equations to follow. The basic results for the monetarist wage equations are shown in Table 2. For the seven countries examined, it gives the coefficients and summary statistics for the unconstrained equations; and, for comparison, it gives the summary statistics for the equation in which the coefficients are constrained to fit the strict monetarist hypothesis. ${ }^{10}$

10. Several objections have been made against the lag structure used in Table 2, especially against the short lag allowed for velocity to return to its proper level. Given the approach used here (see especially pp. 435-36 above), it would be inappropriate to search for the best-fitting lag structure for each variable or each country. Nevertheless, to see whether a longer lag would change the results significantly, one further equation was run, with a three-year distributed lag. The only significant change was an improvement in the standard error for Japan, but the signs continued to be incorrect. 


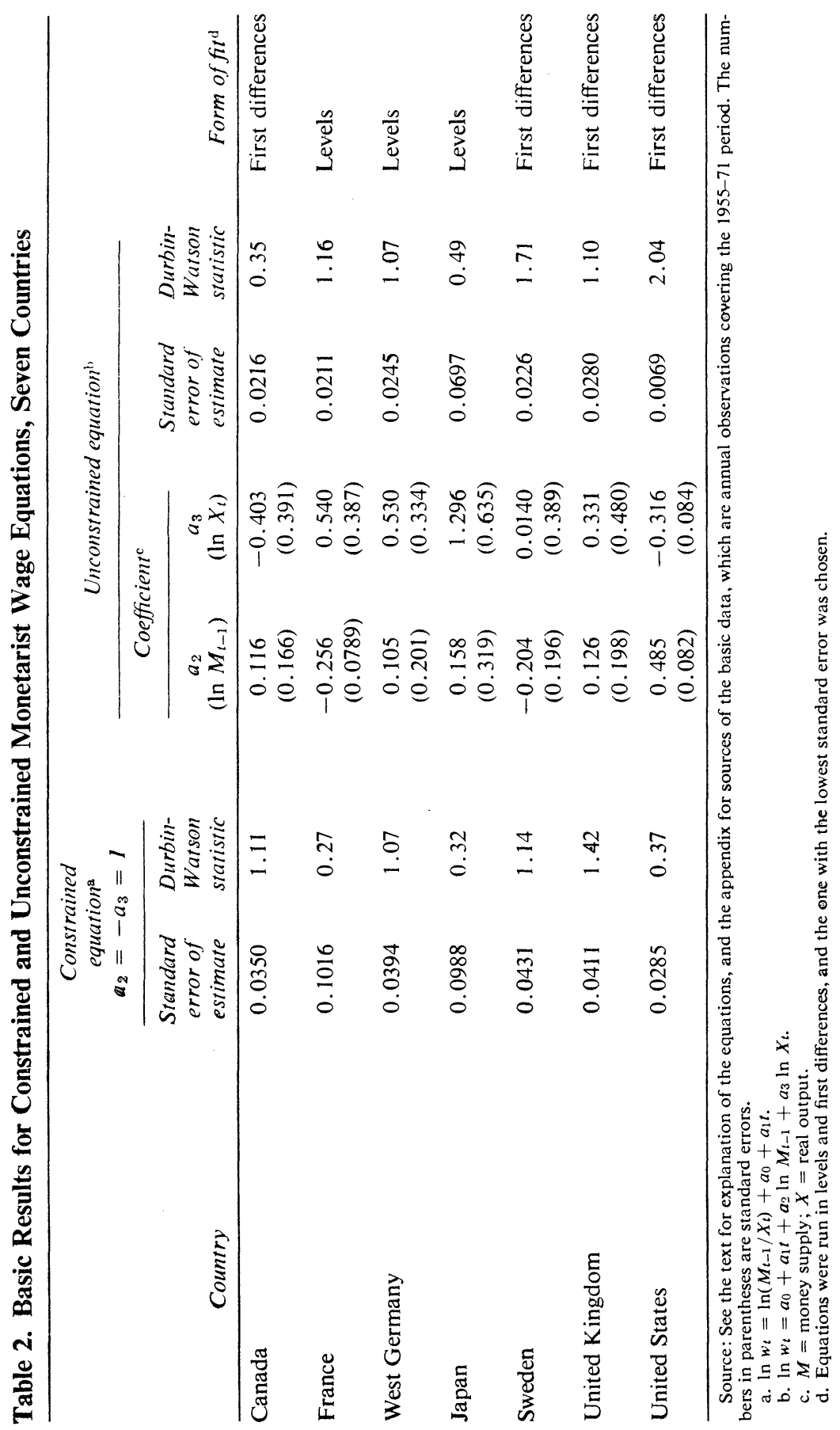


We can summarize the results by noting whether, on the basis of estimates from the unconstrained equation, we can reject the strict monetarist hypothesis that $\mathrm{a}_{2}=-a_{3}=1$. In general (1) the monetarist hypothesis is acceptable if a coefficient is significantly different from zero but not from one; (2) the evidence is insufficient if a coefficient is not significantly different from either zero or one; and (3) the hypothesis is rejected if a coefficient is significantly different from one. ${ }^{11}$ The results are shown in Table 3.

Table 3. Tests of Monetarist Hypothesis, $a_{2}=-a_{3}=1$, Seven Countries and Two Coefficients

\begin{tabular}{lccc}
\hline \multicolumn{1}{c}{ Country or coefficient } & $\begin{array}{c}\text { Accept } \\
\text { hypothesis }\end{array}$ & $\begin{array}{c}\text { Insufficient } \\
\text { evidence }\end{array}$ & $\begin{array}{c}\text { Reject } \\
\text { hypothesis }\end{array}$ \\
\hline Country & 0 & & \\
Canada & 0 & 1 & 1 \\
France & 0 & 1 & 1 \\
West Germany & 0 & 0 & 1 \\
Japan & 0 & 0 & 2 \\
Sweden & 0 & 1 & 2 \\
United Kingdom & 0 & 0 & 1 \\
United States & 0 & 4 & 2 \\
$\quad$ Total & & & 10 \\
Individual coefficient & 0 & 0 & 7 \\
$a_{2}\left(\ln M_{t-1}\right)$ & 0 & 4 & 3 \\
$a_{3}\left(\ln X_{t}\right)$ & 0 & 4 & 10 \\
$\quad$ Total & & & \\
\hline
\end{tabular}

Source: Table 2. For criteria of acceptance and rejection, see text.

Plainly, the strict monetarist hypothesis is rejected whenever the evidence is sufficient. In no country is the hypothesis accepted for either coefficient; in ten cases it is rejected. Even the weak hypothesis that the coefficient on the money supply should be positive is unsatisfactory. The coefficients on the crucial monetary variables are significant in two cases: for the United States (with the right sign) and for France (with the wrong sign).

The theory outlined here is perhaps too literal a rendition of the monetarist viewpoint. Some of the complications are noted by Friedman:

This phenomenon of prices changing by more than the difference between the change in output and the change in money stock is often observed.... How much velocity will change depends on whether the fall in prices or the rise in prices is

11. The philosophy underlying these definitions is that the monetarist hypothesis must do significantly better than the naive hypothesis of a zero coefficient. The criterion is quite close to a likelihood ratio test of the alternatives of zero and unity. 
anticipated. Generally, when inflation has started after a period of roughly stable prices, people initially do not expect prices to continue rising. They regard the price rise as temporary and expect prices to fall later on. In consequence, they tend to increase their monetary holdings and the price rise is less than the rise in the stock of money. Then, as people gradually become wise to what is going on, they tend to readjust their holdings. Prices then rise more than in proportion to the stock of money. Eventually people come to expect roughly what is happening and prices rise in proportion to the stock of money. ${ }^{12}$

In other words, the simple relationship may be complicated by a fall in velocity at the beginning of a monetary expansion, followed by a rise.

One possible reason for the divergence of the coefficients from the unity predicted by the monetarist hypothesis is the movement in velocity noted by Friedman. The idea is that only part of a rise in the money supply is immediately realized in inflation. The rest is realized only with a lag. This might imply, for example, that the proper form is

$$
\ln p_{t}=a_{0}+\sum_{i=1}^{n} a_{1 i} \ln M_{t-i}+\sum_{i=1}^{m} a_{2 i} \ln X_{t-i} .
$$

Assuming $\Delta \ln M_{t}$ and $\Delta \ln X_{t}$ are not autocorrelated, the procedure used above will estimate only $a_{11}$ and $a_{21}$, while the monetarist hypothesis is that

$$
\sum_{i=1}^{n} a_{1 i}=-\sum_{i=1}^{m} a_{2 i}=1
$$

If it seems reasonable to assume that the lag shapes are similar for countries, the estimated coefficients should be similar. According to Table 2 , however, there is no uniformity of size or sign in the coefficients.

This lack of uniformity is perhaps what Friedman has in mind when he writes:

... while inflation or, in the contrary case, deflation, is produced by changes in the stock of money per unit of output, the relationship is not mechanically precise. It is not always the same under all circumstances and it cannot be predicted with precise accuracy. ${ }^{13}$

The same caveats can be applied to Marxian value theory, Ptolemaic astronomy, and Lysenkian genetics.

To what extent can we accept a monetarist interpretation that the recent world inflation is due to an abnormally large rise in the world money supply? We have seen that the wage explosion can be dated from 1968. Table 4

12. Milton Friedman, Dollars and Deficits: Living with America's Economic Problems (Prentice-Hall, 1968), p. 24.

13. Ibid., p. 25. 
Table 4. Prediction Errors in Unconstrained Monetarist Wage Equation, Seven Countries, 1968-71

Percent per year ${ }^{\mathrm{a}}$

\begin{tabular}{lrrrrc}
\hline \multicolumn{1}{c}{ Country } & 1968 & 1969 & 1970 & 1971 & Average \\
\hline Canada & 1.8 & 2.5 & 2.5 & 3.4 & 2.6 \\
France & 3.0 & 1.4 & 0.2 & 2.1 & 1.7 \\
West Germany & -5.3 & 0.3 & 3.7 & 2.6 & 0.3 \\
Japan & -3.3 & 1.5 & 5.0 & 13.0 & 4.1 \\
Sweden & -0.3 & 1.2 & 4.1 & -0.3 & 1.2 \\
United Kingdom & 0.9 & -0.9 & -0.1 & 0.8 & 0.2 \\
United States & 0.5 & 1.0 & 5.8 & 4.0 & 2.8 \\
$\quad$ Average & -0.4 & 1.0 & 3.0 & 3.7 & 1.8 \\
\hline
\end{tabular}

Source: See Table 2

a. Table shows actual minus predicted changes in wages where predicted values are from the unconstrained equation in Table 2.

gives the patterns of residuals-prediction errors-in the seven countries for the four observations since then. ${ }^{14}$ With the exception of the United Kingdom and Germany, all countries (and the average) showed significant residual wage inflation during the period of the explosion.

In summary, the monetarist explanation of the wage explosion is defective. In the first place, the equations do not perform well over the sample period. In the second, they seriously underpredict wage movements during $1968-71 . .^{15}$

\section{Naïve Phillips Curve}

One of the most popular orthodox explanations of wage behavior is the so-called "naïve" Phillips curve. This explanation simply relates the rate of increase of money wage rates or earnings to some measure of labor market tightness, usually the unemployment rate.

The usual form is

$$
\Delta \ln w_{t}=b_{0}+b_{1} \frac{1}{u_{t}}
$$

where $u$ is the unemployment rate.

14. Using the "unconstrained" version evaluates the theory generously. The constrained version performs far worse.

15. The above estimates are probably charitable specifications for the monetarist point of view because of the endogenous nature of the money supply. It is instructive to note that the regressions shown in Table 2 do best for the United States-where monetary policy is relatively active-and do most poorly for Sweden, Germany, and France-where monetary policy is either absent or dictated by external conditions. 
The rationale behind the naive Phillips curve usually runs as follows: ${ }^{16}$ In a given labor market, wages tend to rise under conditions of excess demand, fall with excess supply, and remain constant when excess demands are zero. Since the aggregate unemployment rate is a good indicator of the general state of labor markets, as unemployment decreases, more and more markets come into a state of excess demand and the general pace of wage inflation increases. Because of the frictions in labor markets, however, rising wages, rather than stable wages, would be expected when excess demand for labor is zero (that is, when vacancies equal aggregate unemployment).

Table 5. Naive Phillips Curves, Regression Results, Seven Countries ${ }^{\mathrm{a}}$

\begin{tabular}{|c|c|c|c|c|}
\hline \multirow[b]{2}{*}{ Country } & \multicolumn{2}{|c|}{ Coefficient } & \multirow{2}{*}{$\begin{array}{l}\text { Standard } \\
\text { error of } \\
\text { estimate }\end{array}$} & \multirow{2}{*}{$\begin{array}{l}\text { Durbin- } \\
\text { Watson } \\
\text { statistic }\end{array}$} \\
\hline & $b_{0}$ & $b_{1}$ & & \\
\hline Canada & 0.0116 & $\begin{array}{c}1.97 \\
(1.10)\end{array}$ & 0.0185 & 0.22 \\
\hline France & 0.1015 & $\begin{array}{c}-0.27 \\
(0.29)\end{array}$ & 0.0216 & 1.54 \\
\hline West Germany & 0.0693 & $\begin{array}{c}0.16 \\
(0.13)\end{array}$ & 0.0245 & 1.07 \\
\hline Japan & 0.0524 & $\begin{array}{c}0.51 \\
(0.47)\end{array}$ & 0.0375 & 0.58 \\
\hline Sweden & 0.0383 & $\begin{array}{c}0.57 \\
(0.35)\end{array}$ & 0.0201 & 1.87 \\
\hline United Kingdom & 0.0941 & $\begin{array}{c}-0.46 \\
(0.38)\end{array}$ & 0.0255 & 1.43 \\
\hline United States & -0.0044 & $\begin{array}{c}2.14 \\
(0.58)\end{array}$ & 0.0092 & 1.07 \\
\hline
\end{tabular}

Source: See Table 2.

a. $\Delta \ln w_{t}=b_{0}+b_{1} / u_{t}$, where $w=$ hourly earnings per worker in manufacturing industries and $u=$ civilian unemployment rate.

The Phillips curves discussed here use the civilian unemployment rate as the measure of labor market tightness. More sophisticated measures (such as vacancies or the weighted unemployment rate) might be preferable, but the criterion of data uniformity and time limitations ruled out other variables.

Table 5 gives the regressions of the naïve Phillips curves for the countries

16. See, for example, Lipsey, "Relation between Unemployment and the Rate of Change of Money Wage Rates." 
Table 6. Prediction Errors for Naïve Phillips Curve Regressions, Seven Countries, 1968-71

Percent per year

\begin{tabular}{lrrrrc}
\hline \multicolumn{1}{c}{ Country } & 1968 & 1969 & 1970 & 1971 & Average \\
\hline Canada & 1.6 & 2.5 & 2.7 & 4.2 & 2.8 \\
France & 3.0 & 1.8 & 1.6 & 1.8 & 2.1 \\
West Germany & -3.8 & 1.4 & 3.0 & 2.0 & 0.7 \\
Japan & 4.9 & 6.2 & 4.7 & 3.1 & 4.7 \\
Sweden & -0.6 & 0.9 & 5.0 & 0.3 & 1.4 \\
United Kingdom & 0.8 & 0.2 & 4.5 & 2.5 & 2.0 \\
United States & 0.7 & 0.1 & 0.5 & 2.2 & 0.9 \\
$\quad$ Average & 0.9 & 1.9 & 3.1 & 2.3 & 2.1 \\
\hline
\end{tabular}

Source: Equation used for Table 5.

studied, and Table 6 lists the residuals during the period of the wage explosion. Clearly, the naive Phillips curves do not perform adequately. Except for the United States and Canada, the unemployment rate is not an important variable explaining wage changes, and for France and the United Kingdom, it has the wrong sign. Nor does it explain the wage explosion, as shown by the substantial errors in Table 6, although for the United States, it does fairly well until 1971, and much better than the monetarist equations. The wage explosion of 1968-71 cannot be explained simply by excess demand and tight labor markets.

\section{Expectations Phillips Curves}

For obvious reasons most econometricians have preferred the more sophisticated versions of the Phillips curve. Almost all of them have included current or lagged price change, along with profit rates, vacancy rates, tax rates, lagged wages, wage dispersion, unemployment dispersion, trade union membership, change in money supply, and no end of dummy variables.

The most carefully studied version, sometimes called the expectations hypothesis, includes a proxy measure of the expected rate of inflation. The basic idea is that wages result from a bargaining process rather than decentralized market mechanisms, and that both sides bargain for increases in real rather than money wages. In the strict accelerationist form, a rise in fully anticipated inflation, other things equal, produces an equal rise in wage 
rate increases; in this form, the wage equation is in the long run a real wage equation. The expectations Phillips curve usually takes the following form:

here,

where

$$
\Delta \ln w_{t}=b_{0}+b_{1} \frac{1}{u_{t}}+b_{2} \pi_{t}^{e}
$$

$$
\pi_{t}^{e}=\gamma \sum_{i=1}^{T} \pi_{t-i} \lambda^{i}
$$

$$
\gamma \sum_{i=1}^{T} \lambda^{i}=1
$$

$\pi_{t}$ is the rate of inflation $\left(\Delta \ln p_{t}\right)$, and $\lambda^{i}$ is the weight given to successive past rates of inflation (see the appendix for the exact construction).

The only difficulty for estimation is choosing the coefficients on past inflation, $\lambda$. We have arbitrarily chosen $\lambda=0.8$, and truncated after seven years. The lag structure is of particular importance for two reasons: First, the short lags used in earlier studies ${ }^{17}$ - in the extreme, one quarter-are extremely implausible as a measure of the best distributed lag for the expected rate of inflation. Moreover, the only serious evidence on the question of expectations, an examination of the behavior of interest rates during inflationary periods, shows lags much longer than one quarter. ${ }^{18}$

Second, serious bias can arise from including a price term on the righthand side of a wage equation, especially for the United States. Given the autocorrelated nature of disturbances in most wage equations and the fact that prices tend to be a simple markup on wages, any disturbance in the wage equation will be reflected fairly quickly in the price term. The shorter the lag and the greater the autocorrelation of disturbance, the greater the bias. ${ }^{19}$

17. Thus the following mean lags are found in U.S. Phillips curve studies:

\section{Author}

Eckstein and Brinner, Inflation Process

Perry, "Changing Labor Markets"

R. J. Gordon, "Inflation in Recession and Recovery"

Present study
Mean lag (years)

0.5

0.25

0.25 to 1.1

3.15

18. See the discussion in F. Thomas Juster and Paul Wachtel, "Inflation and the Consumer," Brookings Papers on Economic Activity (1:1972), pp. 71-144; and the various papers in The Economics of Secular Inflation, forthcoming issue of the Journal of Money, Credit and Banking. I am also indebted to my colleague, William Brainard, for pointing out additional pitfalls in the interest rate approach to determining the expected rate of inflation.

19. As a simple example, assume that money wage inflation is a Markov process, 
Since the estimated autocorrelation of the disturbances in naïve Phillips curves tends to be around one-half (for annual estimates), and since, in constructed inflation variables, lags tend to range between one quarter and one year, the universal finding of an expectations coefficient of around onehalf is very suspicious. On the other hand, our constructed estimate is probably reasonably free of estimation bias..$^{20}$

The results for the expectations Phillips curve are shown in Tables 7 and 8. At first blush these are more acceptable than those for the naive Phillips curves (compare them with Tables 5 and 6). This hypothesis performs particularly well for the United States, and reasonably well for Canada, Japan, and Sweden, a pattern of results that is quite plausible on theoretical grounds. On the other hand, the estimates are unacceptable for France and Germany. ${ }^{21}$

One of the interesting aspects of the results is the coefficient on price expectations, $b_{2}$. In a test (with the standard $t$-test and the estimates of the $b_{2}$ coefficients in Table 7) for the possibility that $b_{2}=1$, the accelerationist hypothesis is not rejected for four countries (Japan, Sweden, United Kingdom, United States) and is rejected for three (Canada, France, and West Germany) (see Table 8).

During the period 1968-71, the seven economies exhibit considerable unexplained wage movement even after the sophisticated Phillips curve is taken into account (see Table 9). Even so, this explanation seems to suffice for the United States and, to a lesser extent, Canada.

that the autocorrelation in the wage equation is $\rho$, and that wage increases are immediately passed through into prices. If an expected price variable is constructed as price inflation lagged $\theta$ years, the expected coefficient on the price term will be $\rho^{\theta}$. Thus if $\rho=0.5$ at an annual rate, the bias is as follows:

Average lag (years)
0
0.25
1.00
4.00

Estimated bias (coefficient on
expected inflation)
1.00
0.84
0.50
0.06

20. For a further discussion of this question, see p. 447.

21. The pattern of results is unacceptable for France and Germany if one accepts the hypothesis that the variable $\pi_{t}^{e}$ is indeed the expected rate of inflation. On a different interpretation, William Fellner has pointed out that a negative sign is, in principle, acceptable: People might feel that past inflation, as measured by $\pi_{t}^{e}$, would be followed by deflation. 
Table 7. Expectations Phillips Curve Regression Results, Seven Countries $^{\mathrm{a}}$

\begin{tabular}{|c|c|c|c|c|c|}
\hline \multirow[b]{2}{*}{ Country } & \multicolumn{3}{|c|}{ Coefficient } & \multirow{2}{*}{$\begin{array}{l}\text { Standard } \\
\text { error of } \\
\text { estimate }\end{array}$} & \multirow{2}{*}{$\begin{array}{l}\text { Durbin- } \\
\text { Watson } \\
\text { statistic }\end{array}$} \\
\hline & $b_{0}$ & $b_{1}$ & $b_{2}$ & & \\
\hline Canada & -0.0323 & $\begin{array}{c}1.629 \\
(0.400)\end{array}$ & $\begin{array}{c}2.477 \\
(0.270)\end{array}$ & 0.0075 & 2.64 \\
\hline France & 0.1507 & $\begin{array}{c}-0.144 \\
(0.228)\end{array}$ & $\begin{array}{r}-1.360 \\
(0.651)\end{array}$ & 0.0193 & 1.25 \\
\hline West Germany & 0.0706 & $\begin{array}{c}0.481 \\
(0.116)\end{array}$ & $\begin{array}{c}-1.858 \\
(0.550)\end{array}$ & 0.0174 & 0.88 \\
\hline Japan & 0.0197 & $\begin{array}{c}0.317 \\
(0.406)\end{array}$ & $\begin{array}{c}1.259 \\
(0.623)\end{array}$ & 0.0333 & 0.77 \\
\hline Sweden & -0.0485 & $\begin{array}{c}0.997 \\
(0.627)\end{array}$ & $\begin{array}{c}1.588 \\
(1.905)\end{array}$ & 0.0203 & 1.99 \\
\hline United Kingdom & 0.0543 & $\begin{array}{c}-0.151 \\
(0.389)\end{array}$ & $\begin{array}{c}0.608 \\
(0.890)\end{array}$ & 0.0270 & 1.46 \\
\hline United States & -0.0172 & $\begin{array}{c}1.962 \\
(0.391)\end{array}$ & $\begin{array}{c}0.873 \\
(0.204)\end{array}$ & 0.0062 & 2.36 \\
\hline
\end{tabular}

Source: See the appendix for explanation of the symbols and sources of the basic data, which are annual observations covering the 1955-71 period. The numbers in parentheses are standard errors.

a. Equation 6: $\Delta \ln w_{t}=b_{0}+b_{1} / u_{t}+b_{2 \pi i}$, where $\pi t=\Delta \ln p_{t}$, and $\pi_{i}^{i}=0.253 \pi t-1+0.202 \pi t-2+$ $0.162 \pi t-3+0.130 \pi t-4+0.103 \pi t-5+0.083 \pi t-6+0.067 \pi t-7$, where $u=$ civilian unemployment rate and $p$ is the inflation rate.

Table 8. Characteristics of Coefficients of the Expectations

\section{Phillips Curve}

Number

\begin{tabular}{lll}
\hline & \multicolumn{2}{c}{ Coefficient } \\
\cline { 2 - 3 } Characteristic of coefficient & $b_{1}$ & $b_{2}$ \\
\hline Correct sign & & \\
Significant & 3 & 3 \\
$\quad$ Within a priori range & \\
Insignificant & 0 & 2 \\
Incorrect sign & 2 & 2 \\
Significant & & \\
Insignificant & 0 & 2 \\
\hline
\end{tabular}

Source: See Table 7.

a. This refers to the specification that $0 \leqq b_{2} \leqq 1$ and tests whether the estimated value of $b_{2}$ lies within two standard deviations of this range. 
Table 9. Prediction Errors for Expectations Phillips Curve Regressions, Seven Countries, 1968-71

Percent per year

\begin{tabular}{lrrrrc}
\hline \multicolumn{1}{c}{ Country } & 1968 & 1969 & 1970 & 1971 & Average \\
\hline Canada & 0.7 & 0.1 & -0.6 & 0.5 & 0.2 \\
France & 1.6 & 1.1 & 1.5 & 2.1 & 1.6 \\
West Germany & -1.2 & 1.2 & 2.7 & 3.1 & 1.5 \\
Japan & 3.4 & 4.9 & 3.2 & 1.1 & 3.2 \\
Sweden & -0.8 & 1.0 & 4.9 & 0.4 & 1.4 \\
United Kingdom & 1.3 & 0.6 & 4.7 & 2.9 & 2.4 \\
United States & 0.8 & -0.2 & -0.7 & 0.6 & 0.1 \\
$\quad$ Average & 0.8 & 1.2 & 2.2 & 1.5 & 1.5 \\
\hline
\end{tabular}

Source: See Table 7.

Because the imposed lag is so much shorter than is customary, it appeared useful to test whether a shorter lag would change any of the conclusions of the present paper. Four more ordinary least squares regressions were run with linear declining lags on past price inflation of one, two, three, and four years. The following table shows the standard error of estimate for the various equations:

\begin{tabular}{|c|c|c|c|c|c|c|c|}
\hline $\begin{array}{c}\text { Maxi- } \\
\text { mum } \\
\text { lag } \\
\text { (years) }\end{array}$ & Canada & France & $\begin{array}{c}\text { West } \\
\text { Ger- } \\
\text { many }\end{array}$ & Japan & Sweden & $\begin{array}{l}\text { United } \\
\text { King- } \\
\text { dom }\end{array}$ & $\begin{array}{l}\text { United } \\
\text { States }\end{array}$ \\
\hline 1 & 0.01324 & 0.02213 & 0.02302 & 0.03273 & 0.02076 & 0.02717 & 0.00755 \\
\hline 2 & 0.01168 & 0.02204 & 0.02077 & 0.02908 & 0.02066 & 0.02704 & 0.00716 \\
\hline 3 & 0.01042 & 0.02194 & 0.01790 & 0.02875 & 0.02070 & 0.02675 & 0.00702 \\
\hline 4 & 0.00998 & 0.02166 & 0.01627 & 0.03047 & 0.02082 & 0.02607 & 0.00693 \\
\hline 7 & 0.00750 & 0.01934 & 0.01736 & 0.03326 & 0.02029 & 0.02704 & 0.00618 \\
\hline
\end{tabular}

The countries for which the lag imposed in the Table 7 results seems too long are West Germany and Japan. When the best-fitting new estimate is substituted, the negative coefficient on the $\pi^{e}$ term is magnified for Germany, becoming -3.1 in the best equation, and the residuals are very little changed. For Japan, the unemployment variables develop a negative (and therefore unacceptable) sign. Thus (even ignoring possible bias) the imposed lag does not appear to have discriminated unfairly against the expectations Phillips curve. 


\section{Frustration Theories}

A rather different explanation of the wage explosion in Britain has been advanced by Turner and Wilkinson and supported by Paish and Meade. ${ }^{22}$ This theory holds that the cause of the wage explosion in the United Kingdom was the slowdown in the growth in real net earnings. As Turner and Wilkinson argue:

The 1970 wage explosion may well represent, therefore, one of frustrated-but perhaps not altogether unjustified-expectations. Immediately after the 1967 devaluation, the near-freezing of real consumption could be reasonably argued as necessary to release resources for exports. However, the more recent effect of automatically rising state deductions from wages has been to produce enormous national budget surpluses and increased unemployment.

The impact of price increases and state deductions, together, on real wages is now such that most workers clearly have to run as hard as they can, in wage terms, merely to stay where they are in real or relative ones. ${ }^{23} \ldots$ But the movement of post-tax real wages ... would in fact appear to provide a major explanation of the continuing British wage explosion. ${ }^{24}$

Although the quantitative argument in this article is couched in terms of earnings, several reasons make it more convenient to proceed in terms of real consumption. ${ }^{25}$

The frustration hypothesis has never been seriously tested, so what follows may not do it full justice. The essence of the position is embodied in some combination of the specifications that follow. The first and simplest specification, which might be called a "frustration" Phillips curve, simply adds the rate of growth of consumption to the expectations Phillips curve used above. Thus,

$$
\Delta \ln w_{t}=b_{0}+b_{1} \frac{1}{u_{t}}+b_{2} \pi_{t}^{e}+b_{3} c_{t},
$$

22. See Turner and Wilkinson, "Real Net Incomes and the Wage Explosion"; Meade, Wages and Prices in a Mixed Economy; Paish, "Rise and Fall of Incomes Policy."

23. "Real Net Incomes and the Wage Explosion," p. 310.

24. Ibid., p. 309.

25. The most important reason is the great difficulty in constructing an accurate series on real net wages. To do so requires working out the average direct and indirect taxes paid, as well as careful matching of the price index to eliminate double counting of taxes. Second, to the extent that consumption follows a permanent income or life cycle model, actual consumption will be an accurate barometer of expected income (or expected sustainable consumption). The main disadvantage of using consumption is that if population growth changes rapidly, it may be an inaccurate index of per capita growth in consumption. 
where

$$
\begin{aligned}
c_{t} & =\Delta \ln C_{t} \\
C_{t} & =\text { aggregate consumption expenditures in constant prices. }
\end{aligned}
$$

The a priori sign on $b_{3}$ is negative.

The second specification takes the approach of adaptive expectations. The formation of expectations about $c^{e}$ is assumed to be adaptive at rate $\gamma$ :

$$
c^{e}=(1-\gamma) \sum_{i=0}^{\infty} \gamma^{i} c_{t-1-i}
$$

where

$c^{e}=$ the expected growth rate of consumption

$c=$ the actual growth rate of consumption.

The frustration hypothesis, then, holds that the money wage rate adjusts a fraction, $\delta$, of the difference between actual and expected growth in consumption:

$$
\Delta\left(\Delta \ln w_{t}\right)=\delta\left(c_{t-1}^{e}-c_{t-1}\right)
$$

Lagging (9) one period, multiplying by $\gamma$, and subtracting yields

$$
\Delta\left(\Delta \ln w_{l}\right)=-\delta \gamma \Delta c_{t}+\gamma \Delta \ln w_{t-1} .
$$

The a priori signs on both coefficients ( $\delta$ and $\gamma$ ) are positive.

The summary results for the two specifications are shown in Table 10. Neither seems to have much explanatory power. In the frustration Phillips curve, only two of the estimated coefficients on the consumption variable are significantly different from zero (for the United States and West Germany), but they both have the wrong sign. The coefficient on the United Kingdom (the theory's intellectual domicile) is quite plausible, but it is very poorly determined.

The pure frustration hypothesis fares very poorly. The adaptive term $(\gamma)$ consistently has the wrong sign, as does the composite coefficient $(-\delta \gamma)$. Although the implied coefficients for $\delta$ are plausible, none of the estimates for it is significant.

Given the miserable overall performance of the frustration hypothesis, there seems little point in examining the whole batch of errors for the period of the wage explosion. Table 11 thus deals only with the United Kingdom. The frustration hypothesis, even there, fares no better than its competitors in explaining the wage explosion. 


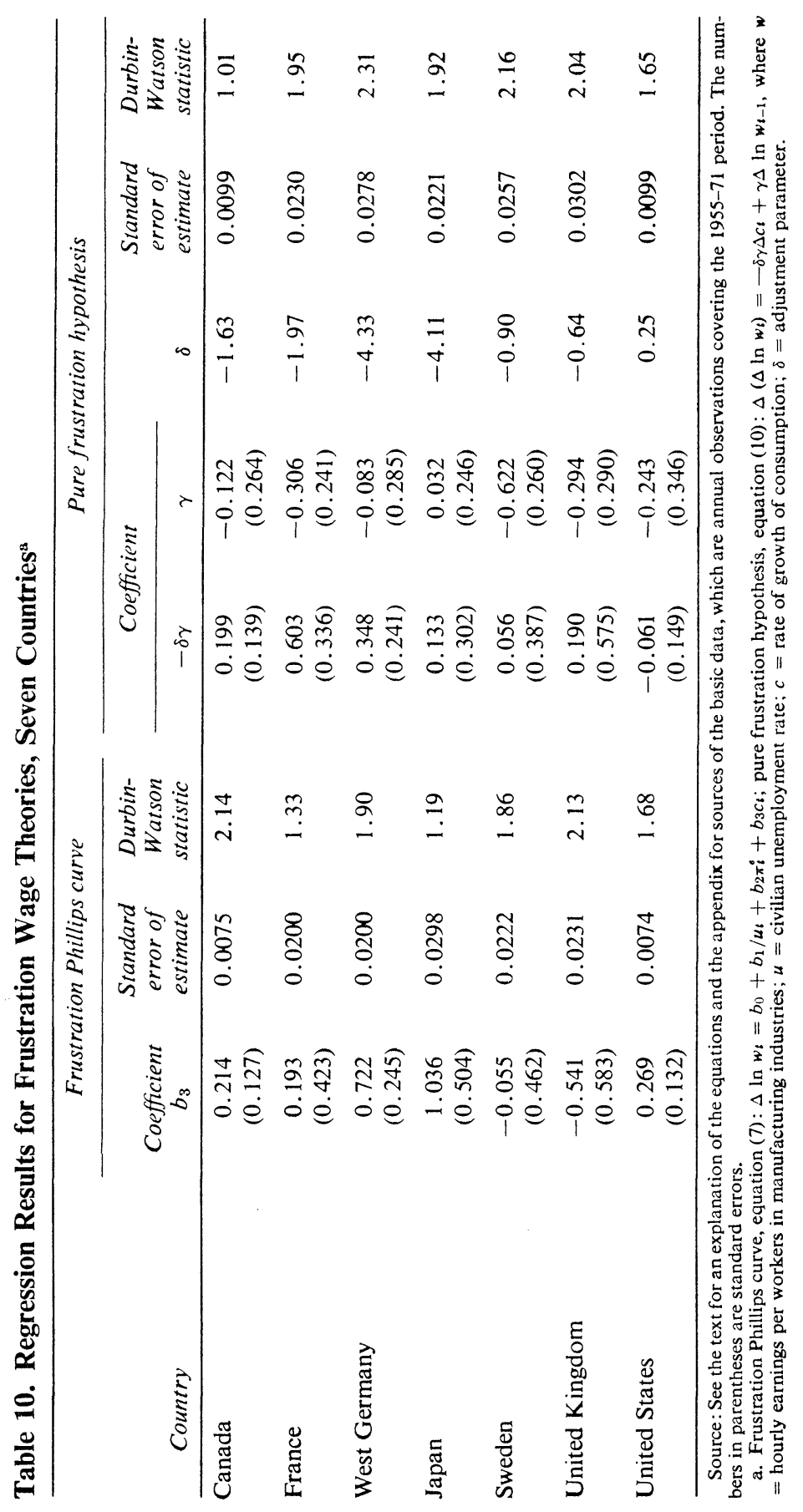


Table 11. Residuals for Regressions for Frustration Wage Theories, United Kingdom, 1968-71

\begin{tabular}{ccc}
\hline Year & $\begin{array}{c}\text { Frustration Phillips } \\
\text { curve }\end{array}$ & $\begin{array}{c}\text { Pure frustration } \\
\text { hypothesis }^{\mathrm{a}}\end{array}$ \\
\hline 1968 & 0.3 & 0.9 \\
1969 & -2.0 & 1.8 \\
1970 & 3.4 & 6.4 \\
1971 & 1.0 & 5.9 \\
Average & 0.7 & 3.7 \\
\hline
\end{tabular}

Source: See Table 10.

a. Assumes no error in levels for 1966 .

\section{Externally Constrained Wage Settlements}

A final general theory of the movement of money wage rates considers the compatibility of wage movements with payments balance. This theory starts with the proposition that in a closed economy a general inflation of goods and factor prices has practically no real effects. Therefore the only forces that constrain the absolute price level in a country are those relating to foreign trade, in particular export and import prices. Obviously, political, social, or ideological constraints on inflation may also force policy makers to keep inflation within certain bounds.

In the polar case of an extremely small open economy with a large fraction of GNP traded or tradable, under fixed exchange rates, the foreign constraint on prices will be practically completely effective. There are only two exceptions: when the economy is virtually closed (as in the case of the United States), and when exchange rates are effectively flexible.

In the postwar monetary system, a prime macroeconomic target has been defense of exchange rates at their par value. As long as countries were forced to regard exchange rate changes as rare and undesirable events, only three policies were available for accomplishing balance-of-payments adjustment: regulating imports by aggregate demand, affecting capital movements by monetary policy, and holding the domestic price level in line with world prices. ${ }^{26}$ Of these, only the last can be regarded as a reasonable longrun strategy for balance-of-payments equilibrium and as a substitute for exchange rate adjustments under the Bretton Woods system.

26. This discussion neglects the differential movement of export prices and other domestic prices. 
What then would be the wage settlement constrained by balance-ofpayments equilibrium? Under a regime of fixed exchange rates and full employment, equilibrium at a given point of time (on, say, basic balance) will be consistent with a price level of $p^{*}(t)$. If prices are a markup $(m)$ on unit labor costs,

$$
p_{x}(t)=(1+m) w(t) A e^{-b t},
$$

where

$$
\begin{aligned}
p_{x}(t) & =\text { export prices } \\
w(t) & =\text { wage rates } \\
A e^{-b t} & =\text { average labor productivity at time } t \\
b & =\text { rate of productivity growth in export industries. }
\end{aligned}
$$

Equilibrium in the balance of payments implies the following equilibrium wage rate:

$$
w^{*}(t)=p^{*}(t)(1+m)^{-1} A^{-1} e^{b t} .
$$

Finally, to breathe life into the hypothesis, the equilibrium price level must be defined, in this case as a price level that keeps the terms of trade constant:

$$
p^{*}(t)=B p_{I}(t)
$$

where $p_{I}(t)$ is import prices. Thus the final hypothesis is:

$$
w^{*}(t)=p_{I}(t)(1+m)^{-1} A^{-1} B e^{-b t},
$$

or, in first differences of the logarithms,

$$
\Delta \ln w^{*}(t)=m_{0}+m_{1} \Delta \ln p_{I}(t), \quad m_{0}<0, m_{1}>0 .
$$

An externally constrained wage rate is thus one that moves with import prices plus the rate of productivity growth in the export industry.

When and where this formulation might be a plausible theory of wage determination depends, first and crucially, on whether a fixed exchange rate system or a monetary union exists. ${ }^{27}$ It is clearly most sensible in a highly open economy where world (and therefore local) prices are effectively exogenous and firms have strong incentives to keep wages at their equilibrium level. Moreover, where capital is mobile, unions may feel sufficiently threatened to accept the equilibrium rate. If unions do not accept the rate, there will be a squeeze on profits, capital movement, and unemployment in

27. We return to this point below. 
the offending industry. Especially if there is differential wage movement among industries, low-inflation industries probably will prosper.

Thus in very open economies, and in exposed industries in less open economies, pressures of the external market are likely to constrain wages to follow the equilibrium rate. The important question is, then, the extent to which the exposed industries will act as a damper or a stimulus to sheltered industries. A Scandinavian model suggests that in periods of full employment, movements in the exposed sector quickly stimulate similar tendencies in the sheltered sector due to "competition for labor in a full employment economy and the 'Solidarity Wage Policy'" of occupational rate equality. ${ }^{28}$

The question, of course, is how big the exposed sector must be relative to the sheltered sector to make it the wage leader. While the exposed sector is quite likely to dominate through this economic mechanism in Sweden and Norway, the proposition is less certain in Germany and France and positively implausible in the United States.

Aside from the pure labor market effect of externally constrained wage rates, the political component of this theory has become increasingly important during the 1960s. The political counterpart of the theory holds that governments have aimed increasingly at full employment, economic growth, and external payments equilibrium as prime objectives. As noted above, the only reasonable manner in which external balance can be maintained is through assuring "price stability," which has come to mean prices that rise no faster than at the world rate. Faced with a crisis in external payments, governments generally turn to a combination of measures restricting capital flows and internal demand, and to wage and price controls (euphemistically called "incomes policies"). To the extent that the economic mechanism fails (for example, when the exposed sector fails to restrain the sheltered sector), governments impose wage and price controls as a substitute.

Although examples are legion, the two most obvious came in the United Kingdom in 1966 and the United States in 1971. When the United Kingdom was faced with a very serious run on sterling and a deteriorating external position, the Labor government responded by instituting severe measures to restrain demand accompanied by a wage and price freeze, a policy that was effective, if only temporarily. Similarly, the new economic policy under

28. Gösta Edgren, Karl-Olof Faxén, and Clas-Erik Odhner, "Wages, Growth and the Distribution of Income," Swedish Journal of Economics, Vol. 71 (September 1969), p. 142. See also Odd Aukrust and others, Instilling fra Utredningsutvalget for inntektsoppgirene (Oslo: 1966) (referred to as the Aukrust Report). 
Table 12. Prediction Errors for Export-constraint Wage Equation, Seven Countries ${ }^{\mathrm{a}}$

\begin{tabular}{lccc}
\hline Country & $\begin{array}{c}\text { Coefficient } \\
m_{1}\end{array}$ & $\begin{array}{c}\text { Standard } \\
\text { error of } \\
\text { estimate }\end{array}$ & $\begin{array}{c}\text { Durbin- } \\
\text { Watson } \\
\text { statistic }\end{array}$ \\
\hline Canada & $\begin{array}{c}0.022 \\
(0.464)\end{array}$ & 0.0220 & 0.11 \\
France & 0.106 & 0.0223 & 1.26 \\
West Germany & $(0.212)$ & & \\
Japan & 0.236 & 0.0273 & 0.98 \\
& $(0.452)$ & & \\
Sweden & 1.039 & 0.0222 & 1.07 \\
& $(0.233)$ & & \\
United Kingdom & 0.674 & 0.0184 & 2.70 \\
& $(0.251)$ & & \\
United States & 0.622 & 0.0209 & 1.34 \\
& $(0.188)$ & & \\
& 0.384 & 0.0098 & 1.22 \\
\hline
\end{tabular}

Source: See the text for an explanation of the equation, and the appendix for sources of the basic data, which are annual observations covering the 1955-71 period. The numbers in parentheses are standard errors.

a. Equation (16): $\Delta \ln w_{t}=m_{0}+m_{1}\left(0.5 \Delta \ln p_{I t}+0.33 \Delta \ln p_{I t-1}+0.17 \Delta \ln p_{I t-2}\right)$, where $w=$ hourly earnings per worker in manufacturing industries and $p_{l}=$ import prices.

the Nixon administration was, according to many informants, basically a response to the disastrous payments deficit of the second quarter of 1971 .

The estimation here used current as well as past import prices, so the final equation is ${ }^{29}$

$$
\Delta \ln w_{t}=m_{0}+m_{1}\left[0.5 \Delta \ln p_{I_{t}}+0.33 \Delta \ln p_{I_{t-1}}+0.17 \Delta \ln p_{I_{t-2}}\right] .
$$

The results of this equation, which are quite encouraging, are shown in Table 12. For Japan, Sweden, and the United Kingdom, the import price term is large and significant, indicating that it could have a large effect on wages.

The errors for the period of the wage explosion are shown in Table 13. They are small for West Germany, Sweden, the United States, Japan, and the United Kingdom, while they remain pronounced for Canada and France.

29. The original version of the paper allowed a more flexible lag. In order to have a symmetric treatment with other theories, it was felt that an imposed lag would be fairer. No studies allow determining a priori what the proper lag is. Given lags both in recognizing the rise in import prices and in renegotiating wage agreements, a declining lag over three years is reasonable. 
Table 13. Prediction Errors for Regressions for Export-constraint Wage Equation, Seven Countries, 1968-71

Percent per year

\begin{tabular}{lrrrrc}
\hline \multicolumn{1}{c}{ Country } & 1968 & 1969 & 1970 & 1971 & Average \\
\hline Canada & 2.0 & 2.7 & 2.5 & 3.4 & 2.7 \\
France & 4.0 & 2.2 & 1.6 & 2.5 & 2.6 \\
West Germany & -4.1 & 0.7 & 3.9 & 2.7 & 0.8 \\
Japan & 3.0 & 2.9 & 0.9 & 0.5 & 1.8 \\
Sweden & -0.5 & -0.1 & 2.6 & -1.7 & 0.1 \\
United Kingdom & -0.9 & -2.1 & 3.7 & 2.7 & 0.9 \\
United States & 1.6 & 1.3 & -0.7 & 0.7 & 0.7 \\
$\quad$ Average & 0.7 & 1.1 & 2.1 & 1.5 & 1.4 \\
\hline
\end{tabular}

Source: See Table 12.

\section{What About Incomes Policies?}

So far this paper has had little to say about the recent social innovation called incomes policies. This is not because we doubt that incomes policies (in some forms, places, and times) can affect the movement of money wages, but because, to record the conclusion from the study by Ulman and Flanagan,

incomes policy, to generalize from the experience of the [seven] countries studied in this account, has not been very successful.... The accumulation of experience in the countries studied ... suggests that in none of the variations so far turned up has incomes policy succeeded in its fundamental objective, as stated, of making full employment consistent with a reasonable degree of price stability. ${ }^{30}$

The irony in this observation is that incomes policy, although not invented in the late 1960s, came ro be employed almost universally by western governments at about the time of the wage explosion. ${ }^{31}$

In any case, the imposition of incomes policies at different times is probably not important for the main subject under consideration here-the wage explosion. There are only two ways in which incomes policies could have caused the wage explosion: (a) if they were extensively and effectively used up to 1967 and then suddenly turned off, or (b) if they were suddenly turned on about 1968, but acted perversely on wage inflation. Both these

30. Lloyd Ulman and Robert J. Flanagan, Wage Restraint: A Study of Incomes Policies in Western Europe (Berkeley: University of California Press, 1971), p. 216.

31. Ibid., chapter on "Conclusions and Prospects." 
positions have been taken by some economists in isolated instances; but they are clearly not accurate for the general picture.

\section{Overall Evaluation}

This examination of the five general theories of wages permits a tentative evaluation of their performance. With standard errors as the criterion of performance, the theories are ranked in Table 14, and the best theory for each country is indicated by bold-face type. These rankings show how well the theories explain wage movements in a given country for the overall period of fit, 1955-71. Table 15 shows the summary results for the period of the wage explosion, 1968-71. Here, too, bold-face type is used to denote the best theory.

\section{Table 14. Rankings of Selected Wage Theories for Seven Countries ${ }^{\mathrm{a}}$}

\begin{tabular}{|c|c|c|c|c|c|c|c|}
\hline \multirow[b]{2}{*}{ Country } & \multicolumn{2}{|c|}{ Monetarist } & \multicolumn{2}{|c|}{ Phillips curve } & \multicolumn{2}{|c|}{ Frustration } & \multirow{2}{*}{$\begin{array}{c}\text { Export- } \\
\text { con- } \\
\text { straint }\end{array}$} \\
\hline & $\begin{array}{c}\text { Con- } \\
\text { strained }\end{array}$ & $\begin{array}{l}\text { Uncon- } \\
\text { strained }\end{array}$ & Naïve & $\begin{array}{l}\text { Expec- } \\
\text { tations }\end{array}$ & Pure & $\begin{array}{l}\text { Phillips } \\
\text { curve }\end{array}$ & \\
\hline Canada & $4^{b}$ & $3^{b}$ & $2^{\mathrm{b}}$ & 1 & $\mathrm{c}$ & c & c \\
\hline France & $2^{b}$ & c & c & c & c. & c & 1 \\
\hline West Germany & $3^{b}$ & c & 1 & c & c & $\mathrm{c}$ & 2 \\
\hline Japan & $4^{b}$ & $\mathrm{c}$ & $3^{b}$ & $2^{b}$ & c & c & 1 \\
\hline Sweden & $4^{b}$ & c & 2 & 3 & c & $c$ & 1 \\
\hline United Kingdom & $n \quad 2^{b}$ & $\mathrm{c}$ & c & c & c & c & 1 \\
\hline United States & $5^{b}$ & 2 & $3^{b}$ & 1 & c & c & $4^{b}$ \\
\hline
\end{tabular}

Sources: See sources and notes for Tables 2, 5, 7, 10, and 12 .

a. The ranking shows 1 for lowest standard error of estimate, 7 for highest. For countries where at least one theory was acceptable, bold-face type indicates the best.

b. Significantly worse than the best equation at the 10 percent level.

c. At least one incorrect sign for a crucial coefficient.

From the general results, it appears that the monetarist viewpoint should be ruled out as a serious theory of wage inflation. For no country does either version of this theory perform better than competing theories. The constrained monetarist version performs especially badly, finishing at or near the end in every race, even when some particularly slow nags are entered. The widespread impression that excessive monetary expansion was the chief causal factor in recent inflations is clearly not founded on empirical association. ${ }^{32}$

32. It must be reiterated that in many of the other theories monetary policy plays a partial role in determining inflation. Thus in the Phillips curve theories, monetary 
Table 15. Comparison of Prediction Errors for Selected Wage Theory Regressions, Seven Countries, Wage Explosion Period, 1968-71

Mean prediction errors, percent per year ${ }^{\mathrm{a}}$

\begin{tabular}{|c|c|c|c|c|c|c|c|}
\hline \multirow[b]{2}{*}{ Country } & \multicolumn{2}{|c|}{ Monetarist } & \multicolumn{2}{|c|}{ Phillips curve } & \multicolumn{2}{|c|}{ Frustration } & \multirow{2}{*}{$\begin{array}{l}\text { Export- } \\
\text { con- } \\
\text { straint }\end{array}$} \\
\hline & $\begin{array}{c}\text { Con- } \\
\text { strained }\end{array}$ & $\begin{array}{l}\text { Uncon- } \\
\text { strained }\end{array}$ & Naïve & $\begin{array}{l}\text { Expec- } \\
\text { tations }\end{array}$ & Pure & $\begin{array}{l}\text { Phillips } \\
\text { curve }\end{array}$ & \\
\hline Canada & 1.6 & 2.6 & 2.8 & $0.2^{\mathrm{a}}$ & b & $b$ & b \\
\hline France & 2.4 & $\mathrm{~b}$ & b & $b$ & b & b & 2.6 \\
\hline West Germany & 0.7 & b & 0.7 & b & b & $b$ & 0.8 \\
\hline Japan & 9.3 & b & 4.7 & 3.2 & $b$ & b & $1.8^{\mathrm{a}}$ \\
\hline Sweden & -1.0 & b & 1.4 & 1.4 & b & b. & $0.1^{\mathrm{a}}$ \\
\hline \multicolumn{8}{|l|}{ United } \\
\hline Kingdom & -2.3 & $\mathrm{~b}$ & b & b & $\mathrm{b}$ & b & $0.9^{a}$ \\
\hline United States & 2.0 & 2.8 & 0.9 & $0.1^{\mathrm{a}}$ & b & $\mathrm{b}$ & 0.7 \\
\hline
\end{tabular}

Sources: See sources and notes for Tables 2, 5, 7, 10, and 12 .

a. For countries where at least one theory seems acceptable, the best is indicated by bold-face type.

b. At least one incorrect sign for a crucial coefficient.

It is equally apparent that frustration theories of the wage movement do not perform sufficiently well to be taken seriously. As Table 10 demonstrates, the signs are wrong in almost all regressions. The frustration Phillips curve does better than any other single explanation for the United Kingdom only because the unemployment term has the wrong sign. The only other country for which the frustration theory does well is Japan.

Eliminating the monetarist and frustration theories leaves two general classes of explanations, the Phillips curve explanations and the exportconstraint theories.

The Phillips curve approach provides an adequate empirical explanation for wage movements in the United States and Canada. This empirical result is supported by the theoretical considerations (outlined above) implying that Phillips curve approaches should do rather better in these two countries than in the others. According to Table 15, the expectations Phillips curve approach gives nearly unbiased predictions during the period of the wage explosion in both these countries. That the wage explosion in the

policy, along with fiscal policy and other demand determinants, helps determine aggregate demand. Inflation is then determined as the pressure of demand works its way through the system. This partial association of monetary policy with inflation should not be confused with the total association of the monetarist viewpoint. The refutation of the monetarist proposition that "only money matters" does not imply the proposition that "money does not matter." 
United States and Canada was due to the effects of tight labor markets and the lagged effect of the consequent inflation is, then, the tentatively accepted view.

On the other hand, the Phillips curve does not appear to be an adequate explanation of wage movements in the other, smaller, countries. With the exception of Sweden, the Phillips curve approach is distinctly inferior, and in most cases has incorrect signs (it gives an upward sloping Phillips curve in the United Kingdom!). Clearly, other important forces were at work in these countries.

The export-constraint theory of wage movements appears to be the most adequate explanation for Japan, Sweden, and the United Kingdom. In these three countries, it is statistically the most satisfactory. Furthermore, it explains the period of the wage explosion quite well for both Sweden and the United Kingdom, and better than other theories for Japan (see Table 15).

In summary, the export-constraint theory appears to do quite well for open economies in which wages are plausibly linked to foreign trade. It was not expected in any case to perform well for either the United States or Canada, but the cases of Germany, and especially France, remain somewhat puzzling. In Germany, the period under study probably should be broken at 1960 . Until that year, West Germany had considerable unemployment due to the postwar reconstruction and labor immigration. After 1960, with the construction of the Berlin wall and slowdown of immigration from Southern Europe, unemployment declined to slightly less than 1 percent. Only after 1960 was the labor market in the kind of equilibrium in which explanations like the Phillips curve or the export-constraint theory could be reasonably satisfactory. ${ }^{33}$

France's inflation, like its history, is sui generis. French history takes its landmark dates from revolutions. Thus the wage explosion must be dated from les événements de mai-juin 1968. For the preceding decade, French workers had become accustomed to wage increases of between 6 and 8 percent. Suddenly, from 1968 on, wage settlements have been between 10 and 12 percent. No obvious economic factor explains the 1968 mini-revolution and its inflationary aftermath: Unemployment was slightly

33. A batch of regressions was run for Germany using the sample period 1961-71. For this period, naïve Phillips curves performed better than any other theory, with a standard error of estimate 25 percent lower than that for 1956-71. This implies a significant break in structure between the two periods. 
higher after 1967; and, up to the devaluation of 1969, import prices were stable and consumer prices chugged along with increases of less than 3 percent annually.

\section{Implications}

The results are messy, but there does emerge a fairly coherent picture of the wage explosion in the late 1960s. The wage inflation in the United States and Canada can be attributed to the tightness of the labor markets. Outside of North America the rise in wages can be more tenably ascribed to the permissive economic climate generated by a rise in import prices.

What then is the initiating force in the worldwide inflation? Figure 2 tells the story. It shows the simple averages of the rate of wage inflation for North America (the United States and Canada) and for the other five countries (France, Germany, Japan, Sweden, and the United Kingdom). After the period of tranquility (1958 to 1964) the rate of wage inflation in the North American countries began to rise. It became especially steep as a result of the strains imposed by the Vietnam war boom and the associated mismanagement of aggregate demand starting in $1966 .^{34}$

The response in the other countries did not, evidently, come gradually. Rather, there were sharp jumps in 1968, 1969, and 1970. Although the suddenness of the response in the five countries is slightly surprising, ${ }^{35}$ the precedence of the inflation in North America is unmistakable. Together with the econometric evidence presented above, the evidence on the lags suggests quite strongly that the rise in the general level of world prices was indeed the most significant causal factor of the wage explosion in countries outside of North America.

How does the United States exert such a powerful influence on prices abroad? Paradoxically, the answer is because the United States is the only country that does not (or can afford not to) care seriously about the effect of its price level on its external position. With the possible exception of the

34. For an insider's view of "the inflation goof," see Arthur M. Okun, The Political Economy of Prosperity (Brookings Institution, 1970), Chap. 3.

35. The dip in 1967 is slightly misleading. A glance at Table 1 shows that it is due almost entirely to dips in two countries-the United Kingdom and Germany-caused in the first case by the July 1966 measures in the United Kingdom, which imposed a freeze on wages and prices, and, in the second, by the sharp recession in Germany. 


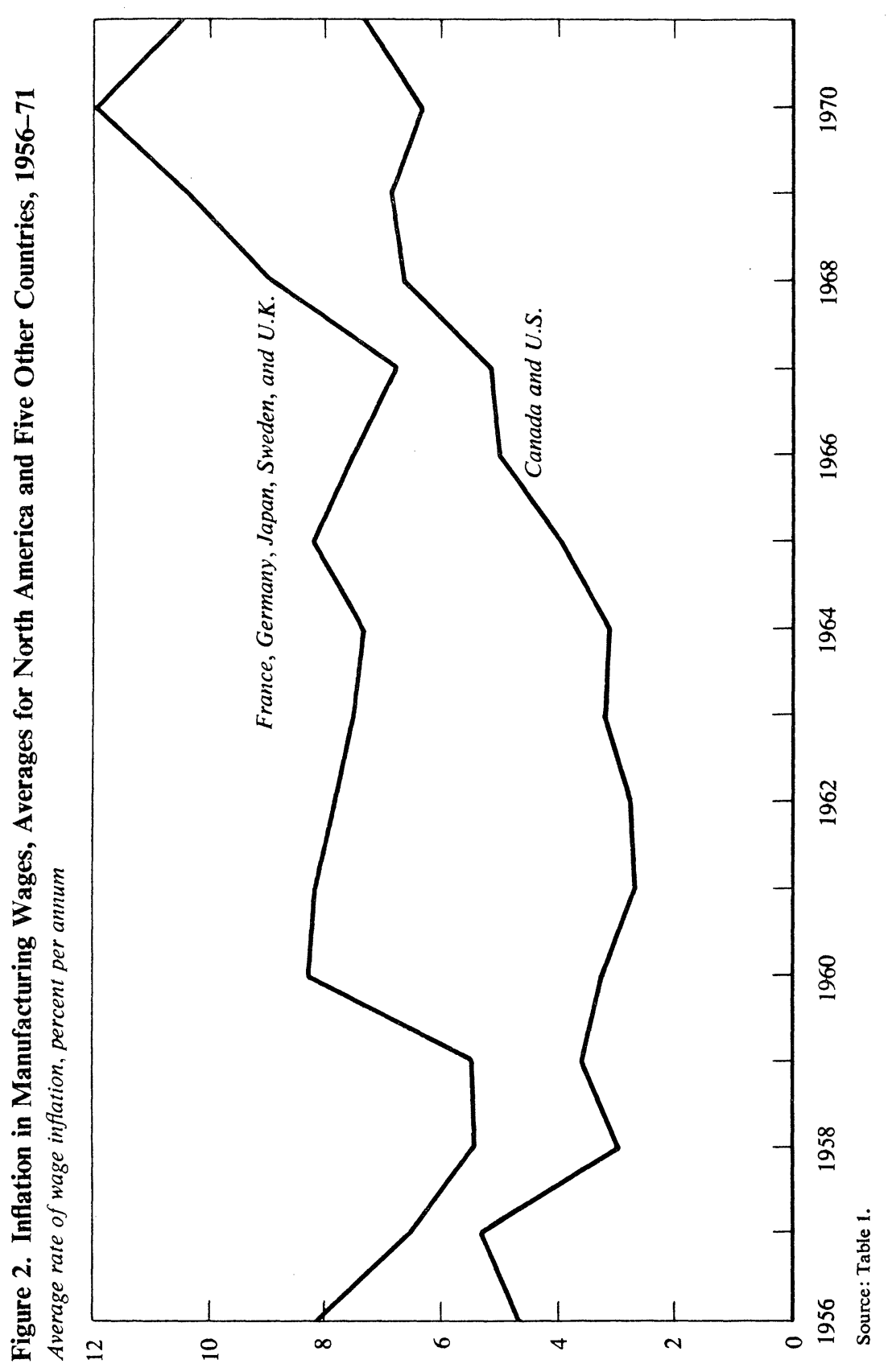


early 1960s, U.S. domestic policy has never been seriously constrained by anxieties about the effects of expansion on the balance of payments. Compare this insouciance with the primitive "stop-go" management in the United Kingdom described by Samuel Brittan:

In the 1950s and early 1960s the Treasury behaved like a simple Pavlovian dog responding to two main stimuli: one is "a run on the reserves," and the other is "500,000 unemployed." 36

If, under a regime of fixed exchange rates, all other countries follow a course of domestic demand management with an eye to maintaining balance-of-payments equilibrium through price restraint, the United States will determine the world inflation rate. This is, formally, the solution to the well-known " $n$-country problem" in international payments adjustment. If the United States suddenly became active instead of passive with respect to its payments balance (some evidence of this appeared under the new economic policy initiated in August 1971), the payments targets might be inconsistent; in this case other countries might help determine the world inflation rate. As long as the United States is passive in payments policy, it can have the last word in inflation policy.

All this depends crucially on the fact that other countries make a totem of stable exchange rates. With increasing frequency in the last few years, countries have used exchange rates rather than internal wages and prices as the medium of external adjustment. How would the prospects for world inflation change if the trend toward freely floating rates were fully realized? Bankers and hauts financiers hold to the credo that freely floating exchange rates would be "inflationary." ${ }^{37}$ If the evidence outlined here is correct, the inflationary consequences of floating exchange rates for countries other than the United States are indeed serious. If the only firm peg on which to hang domestic prices is the external price level, its removal might well loosen restraints and produce serious inflations in these countries. No one in the dialogue about floating rates has suggested a substitute for this restraint on inflation.

36. The Treasury under the Tories, 1951-1964 (Penguin, 1964), p. 288.

37. Even the strongest proponent of floating exchange rates, Milton Friedman, admits this objection may have merit "for countries . . . that have been susceptible to highly inflationary policies, that have been willing to submit to the discipline of the balance of payments, and for which foreign trade is a substantial part of total trade." Milton Friedman, "First Lecture," in Milton Friedman and Robert V. Roosa, The Balance of Payments: Free versus Fixed Exchange Rates (American Enterprise Institute for Public Policy Research, 1967), p. 22. 


\title{
APPENDIX
}

\section{Symbols and Sources of Data \\ Used in Regressions}

\begin{abstract}
THIS APPENDIX PROVIDES a list of the variables used in this paper, together with their sources, and a key to the abbreviations used to identify the sources.
\end{abstract}

\section{Symbols and Sources}

\begin{tabular}{|c|c|c|}
\hline Symbol & Name of variable and explanatory notes & Source \\
\hline$C$ & $\begin{array}{l}\text { Consumption expenditures at constant } \\
\text { market prices; for the most part, these } \\
\text { use standard U.N. techniques. Values } \\
\text { for } 1971 \text { are preliminary for Sweden, } \\
\text { Germany, and France. }\end{array}$ & $\begin{array}{l}\text { ERP, UN/SY, } \\
\text { UN/NAS, } \\
\text { OECD/MEI }\end{array}$ \\
\hline$h$ & $\begin{array}{l}\text { Average weekly (monthly for Japan) hours } \\
\text { per worker }\end{array}$ & $\begin{array}{l}\text { ERP, UN/SY, } \\
\text { OECD/HS, } \\
\text { OECD/MEI, } \\
\text { UK/G }\end{array}$ \\
\hline$I, p_{I}$ & $\begin{array}{l}\text { Indices of unit volume and unit value of } \\
\text { imports, respectively; } 1963=100\end{array}$ & $\begin{array}{l}\text { ERP, } \\
\text { OECD/HS, } \\
\text { OECD/MEI }\end{array}$ \\
\hline$M$ & $\begin{array}{l}\text { Money supply, generally defined as the } \\
\text { sum of demand deposits and currency } \\
\text { in circulation, that is, } M_{1} \text {; the data are } \\
\text { year-end values, so } M_{t-1} \text { refers to the } \\
\text { money supply lagged six months. }\end{array}$ & $\begin{array}{l}\text { ERP, UN/SY, } \\
\text { OECD/HS, } \\
\text { OECD/MEI }\end{array}$ \\
\hline$p$ & $\begin{array}{l}\text { Consumer price index (base-weighted } \\
\text { Laspeyres indices, usually based on } \\
1963 \text { weights) }\end{array}$ & $\begin{array}{l}\text { ERP, UN/SY, } \\
\text { OECD/HS, } \\
\text { OECD/MEI, } \\
\text { UK/G }\end{array}$ \\
\hline
\end{tabular}


Symbol. Name of variable and explanatory notes

$u \quad$ Civilian unemployment rate

$w$

$\pi^{e}$

\section{$X$}

Gross national (or domestic) product at constant market prices

Lagged historical inflation rate, or ex-
Source

ERP, UN/SY,

OECD/LFS, OECD/MEI, $\mathrm{UK} / \mathrm{G}$

ERP, UN/SY, OECD/HS, OECD/MEI, $\mathrm{UK} / \mathrm{G}$

ERP, UN/SY, UN/NAS, OECD/MEI pected rate of inflation. This series is generated from lagged actual inflation $\left(\Delta \ln p_{t}\right)$ according to a geometric lag with a weight of adaptation of price expectations of 0.8 truncated after seven years:

$\begin{array}{ll}\text { Year lag } & \text { Weight } \\ 1 & 0.253 \\ 2 & 0.202 \\ 3 & 0.162 \\ 4 & 0.130 \\ 5 & 0.103 \\ 6 & 0.083 \\ 7 & 0.067 \\ \text { Mean lag } & 3.15 \text { years }\end{array}$

Key to Sources

ERP

Economic Report of the President Together with the Annual Report of the Council of Economic Advisers, January 1972. 
$\mathrm{UN} / \mathrm{SY}$

UN/NAS

OECD/HS

OECD $/$ LFS

$\mathrm{OECD} / \mathrm{MEI}$

$\mathrm{UK} / \mathrm{G}$
United Nations, Statistical Yearbook, various issues

United Nations, Yearbook of National Accounts Statistics, various issues.

Organisation for Economic Co-operation and Development, Main Economic Indicators: Historical Statistics, 1959-1969 (Paris: OECD, 1970), and earlier volumes.

Labour Force Statistics, various issues.

Main Economic Indicators, various issues.

Department of Employment Gazette (London: HeI Majesty's Stationery Office), various issues.

\section{Discussion}

THERE WAS AN EXTENDED DISCUSSION of how far one should go on the basis of Nordhaus' rather simple equations in drawing conclusions either about alternative explanations of inflation or about differences among countries. Saul Hymans pointed out that specialists from each country involved would have far more sophisticated models of their own economies than those used by Nordhaus in testing any of the theories he examines. Lawrence Klein agreed there was a need to explain the current inflation in some unifying way for all the countries involved. But he argued that to do this, one had to take a hard look at every country individually in order to incorporate crucial institutional differences into the wage equations for each before attempting to test any particular theory. In order to estimate common parameters well amiong countries, it is essential to take account of specific variables or structural characteristics in individual countries. He and several other participants cited institutional factors specific to several countries that they regarded as essential to understanding the wage behavior in each.

Robert Solow countered that, while such detailed modeling might be essential for many purposes, he took Nordhaus' paper to address a question 
for which his more summary equations could be useful: Is there some elementary, common explanation for the sharp acceleration in inflation that occurred in every country for the last several years? Nordhaus concurred with Solow's interpretation and emphasized that he was not attempting to construct the best equation for predicting wage movements in each country. He added that some elaborate predicting equations, such as the OECD equation for German wages, probably had little value for detecting what really governed wage movements since they were constructed after so much experimentation with the data in order to get the best fit to the historical record.

Nordhaus' rejection of the monetarist wage model generated comments from many panel participants. R. J. Gordon felt that the analysis should center on the "academic" statements of Friedman and other monetarists and not on Friedman's "polemic" statements. Gordon found Friedman's academic wage model to be very similar to the expectations Phillips curve equations tested in the paper. William Fellner suggested that the essential core of the monetarist argument was that a change in the fiscal deficit without a change in the money supply has no effect on income because an increase in the deficit "crowds out" an equivalent amount of private expenditures. If this is the essential element in the monetarist theory, Fellner thought it impossible to test its significance without further development of the Nordhaus framework.

Fellner discussed the implications for the behavior of inflation under flexible exchange rates of Nordhaus' results supporting the export-constraint hypothesis. He noted that it is not clear that the introduction of flexible exchange rates would free economic policy makers from their politically perceived obligation to restrain inflation. He contended that it made little difference whether the currency of a country was declining in value under flexible rates or it was on its way to losing all its reserves under fixed rates; in either case, policy makers might or might not assume their anti-inflationary obligations since they might or might not prevent a continuous decline of their flexible rates and might or might not prevent abrupt devaluations of their so-called fixed rates. Lawrence Krause noted that the effect of flexible exchange rates on the domestic economy depends very much on whether deflation or inflation is being transmitted. If it is inflation, flexible exchange rates would make it easier to minimize the domestic inflation effects since exchange rate adjustments would then offset the impact of the external inflation by keeping import prices down. 